\title{
Effects of Government Education and Health Expenditures on Economic Growth: A Meta-analysis
}

Sefa Awawoyi Churchill

Monash University

Siew Ling Yew

Monash University

And

Mehmet Ugur

University of Greenwich

Year: 2015

No: GPERC21 
Abstract: Using a sample of 306 estimates drawn from 31 primary studies, this paper conducts an empirical synthesis of the link between economic growth and government expenditure on education or health using meta-analysis. We also explain the heterogeneity in empirical results. We find that the effect of government education expenditure on growth is positive, whereas the growth effect of government health expenditure is negative. Our meta-regression analysis suggests that factors such as econometric specifications, publication characteristics as well as data characteristics explain the heterogeneity in the literature. We also find no evidence of publication selectivity.

JEL code: O40, H50, C1

Keywords: government education expenditure; government health expenditure; human capital; economic growth

Acknowledgements: We would like to thank two anonymous reviewers of the Program Committee of MAER-Net Colloquium 2014 in Athens; and the participants in the conference for helpful comments.

Correspondinf Author: Sefa Awawoyi Churchill: Department of Economics, Monash University, VIC 3800, Australia·Email: sefa.awaworyi@monash.edu

Siew Ling Yew: Department of Economics, Monash University, VIC 3800, Australia Email: siew.ling.yew@monash.edu

Mehmet Ugur: Business School, University of Greenwich, London, UK·Email: $\underline{\text { m.ugur@gre.ac.uk }}$ 


\section{Introduction}

Economists have long recognised that human capital is important for economic growth (see e.g., Schultz, 1961; Becker, 1964; Uzawa, 1965; Rosen, 1976). Schultz asserts that investments in human capital such as expenditures on education and health account for most of the rise in the real earnings per worker. According to Becker (1964), investments in human capital raise an individual's productivity and earnings. The basic idea is that a highly educated and healthier workforce is expected to be relatively more productive. Subsequent work has also emphasized the importance of human capital in explaining growth or growth differences among countries (see e.g., Lucas, 1988; Mulligan and Sala-i-Martin, 1993; Barro and Sala-i-Martin, 1995).

There are empirical studies that confirm human capital is important for long-run growth (see, e.g., Romer, 1986; Barro, 1991; Levine and Renelt, 1992; Mankiw et al., 1992; Barro and Lee, 1993; Bassanini and Scarpetta, 2001; Krueger and Lindahl, 2001; Baldacci et al., 2004). However, some other studies have surprisingly found weak association between human capital and growth, and even negative effects (see Benhabib and Spiegel, 1994; Bils and Klenow, 2000; Caselli et al., 1996; Islam, 1995; Knight et al., 1993; Pritchett, 1996). There are several explanations for the lack of a robust association between human capital and growth. For instance, according to Levine and Renelt (1992), model specification and the inclusion or exclusion of certain control variables could explain differences in reported estimates.

Though health has been recognised as another fundamental element of human capital (see e.g., Schultz, 1961; Bloom et al., 2001; Barro, 2013), human capital has often been restricted to only education in the literature of economic growth and development. At the same time, government has played a crucial role in the investments in both basic education and 
primary health care in most countries. However, the empirical evidence about their growth impacts is mixed and inconclusive. ${ }^{1}$

In this paper we re-assess the growth effect of government education expenditure as well as the growth effect of government health expenditure. We combine results from various studies that empirically investigate the effect of government expenditure on education or health (henceforth GEH) on economic growth to identify sources of heterogeneity amongst these results, and to derive a more precise effect size estimate than that derived in a single empirical study.

Since human capital investments are essential for the accumulation of human capital and human capital has been stressed as the key engine of growth in endogenous growth theory, we formulate hypotheses that reflect a positive GEH-growth association. Thus, based on 31 primary studies with 306 meta-estimates, we formulate three hypotheses $(\mathrm{H} 1-\mathrm{H} 3)$ to examine the GEH-growth relationship: (H1) government education expenditure as a share of GDP promotes growth, (H2) government health expenditure as a share of GDP promotes growth, and (H3) government expenditure on human capital (education and health combined) as a share of GDP promotes growth. We also examine H1-H3 for both developed and less-developed counties (LDCs). We find that the effect of government education expenditure on growth is positive whereas a negative growth effect is observed for government health expenditure. When we use a combined measure- government expenditure on both education and health, we obtain a positive growth effect. We also find that $(\mathrm{H} 2)$ is not supported for developed countries. This study makes a number of important contributions. First, we investigate if 'genuine' effect beyond publication bias exists between GEH and economic growth. Without any control for

\footnotetext{
${ }^{1}$ For instance, Landau (1983, 1986), Stroup and Heckelman (2001), and Afonso and Jalles (2013) find a positive effect of government education expenditure on growth, while Blankenau, Simpson, and Tomljanovich (2007) find a negative growth effect of government education expenditure. Similarly, empirical studies that investigate the growth effect of government expenditure on health provide mixed results (see e.g., Easterly and Rebelo, 1993; Landau, 1997; Cooray, 2009).
} 
publication bias, results from empirical literature could be misleading (Stanley, 2008) and thus, could impede the policy formulation process. We deal with issues of publication selection bias, and accordingly provide a statistically valid conclusion on the relationship between GEH and growth.

Second, we investigate various sources of heterogeneity in the empirical literature that examines the GEH-growth relationship. Without addressing issues of heterogeneity, a general conclusion cannot be drawn on the GEH-growth relationship. This is mainly due to the disparity in the empirical literature, especially with regards to the data used, estimation methods, and the underlying theoretical models, among others. Thus, with the use of metaregression analysis, we control for study-to-study variations which allow for the determination of a net effect of GEH on growth.

Third, we capture country differences and provide a general conclusion per development level (i.e., developed countries and LDCs). With our results, we lay a foundation for, and guide future studies in examining areas of particular importance in the human capital expenditure-growth literature. For instance, we note that very few studies examine the impact of government health expenditure as share of GDP on economic growth. Thus, future studies can examine this relationship more thoroughly.

To the best of our knowledge, this is the first study that presents a detailed empirical synthesis on the GEH-growth relationship using meta-analysis. Benos and Zotou (2014), using meta-analysis, investigate a similar research question. However, instead of investigating the growth effects of GEH, they examine the effect of education measured by literacy, enrolment and schooling years, on economic growth. They provide evidence of publication bias towards the positive effects of education on growth. Effects of education on growth also vary significantly depending on the measure of education. 
This current study is relevant in practice, given the ongoing debate on how various components of government expenditure affect growth. Thus, from the policy perspective, our results suggest that education, relative to health, is a more important sector in promoting growth. Therefore, to promote growth, education relative to health may be a key sector to which public expenditure should be directed in the context of tight government budget constraints or budget deficits. Moreover, the positive growth effect of the combined government human capital expenditure (i.e., the combined government expenditure on education and health) obtained in this metaanalysis may imply that the positive effect of government human capital expenditure on economic growth may be largely through its impact on improved education and the positive spill-over effects that public schools generate. ${ }^{2}$

\section{Brief Overview of Existing Perspectives}

\subsection{Education}

Education has been considered as one of the most significant investments in human capital and has been discussed extensively in the literature of economic growth. It has been argued that education can affect growth through many different mechanisms. For instance, education can affect growth by increasing the efficiency of the workforce, by reducing inequality, by promoting health, by reducing fertility levels, by creating better conditions for good governance, and by increasing the knowledge and the innovative capacity of an economy (Aghion et al., 1999; Castelló-Climent and Doménech, 2008; Lipset, 1960; Glaeser et al., 2004; Castelló-Climent, 2008; Benhabib and Spiegel, 1994; Hanushek and Woessmann, 2008).

\footnotetext{
${ }^{2}$ There are empirical studies (e.g., Moretti, 2004a, 2004b) that document human capital externalities through funding public schools.
} 
There are many theoretical papers that investigate the interaction between government education expenditure and growth. Among those papers are Glomm and Ravikumar (1992, 1997, 1998), Eckstein and Zilcha (1994), Zhang (1996), Kaganovich and Zilcha (1999), Cassou and Lansing (2001), Benabou (2002), Blankeanu (2005), and Wigger (2004). Glomm and Ravikumar (1992), for instance, examine the implication of schooling on growth and income inequality and find that public education can yield greater per capita incomes when the initial income inequality is sufficiently high in an overlapping-generations model. Zhang (1996) finds that education subsidization stimulates growth and reduces welfare losses caused by human capital externalities.

The empirical evidence with regards to government education expenditure and economic growth however has been mixed. Zhang and Casagrande (1998), Barro and Sala-i-Martin (1995), and Baldacci et al. (2008) find a positive association between government education expenditure and economic growth. Easterly and Rebelo (1993) find the positive relationship only for some specifications, while Devarajan et al. (1996), Landau (1986), Levine and Renelt (1992), and Keller (2006) find insignificant connection between the two.

\subsection{Health}

One direct channel through which health can affect economic growth is by increasing workforce productivity. By treating health as a capital good in his model, Grossman (1972) argues that people are born with initial health endowments that depreciate over time but can grow with investments in health. Grossman demonstrates that increase in health capital reduces the time lost to illness and thus, health allows a more effective performance that increases productivity. Jack (1999) indicates that the productivity of a labour force depends on investments in human capital and also the physical and mental capabilities of the workforce. The literature review by Strauss and Thomas (1998) presents a series of evidence supporting 
the relationship between productivity and health. Bloom and Canning (2000) also suggest that healthy communities or populations tend to have enhanced physical abilities and mental clarity which in turn increases productivity.

Health can also affect growth indirectly when health status affects education performance. Good health can be associated with increased levels of schooling and high education performance. Barro (1996) finds that there is an incentive to invest in education given an increase in health indicators. Thus, for children who are chronically ill, parents may not have an incentive to invest in their education. This establishes a strong link between education and health and more specifically goes to support the arguments projecting health as a human capital component. Similarly, given the need to take care of sick relatives, labour productivity may be reduced and more importantly, years of schooling may be reduced for children if parents are chronically ill.

Thirdly, health makes development more achievable. Sorkin (1977) suggests that in areas where economic activity has been hindered owing to unfavourable health condition, an investment into a robust major health programme could be a catalyst to promote development. This argument is in line with assertions made by Bryant (1969) who indicates that economic development as well as social changes within the developing world can be improved with an enhancement in health and health services.

In addition, health can affect growth through its effect on wealth and income. There is a large body of literature which suggests that there is a positive effect of health on wealth. With an increase in the wealth levels of individual in an economy, economic growth is enhanced. Related to this, Lillard and Weiss (1997), and Smith (1998) establish a link between health and future income. Furthermore, given the positive impact of health on education performance, higher education tends to increase productivity and consequently, leads to higher wealth or income. 
Compared to the empirical literature on the effect of education on growth, the empirical literature on the effect of health on growth is relatively thin. Using data from developing and developed countries in 1965-1990, Jamison et al. (2004) find that improvements in health account for about one tenth of economic growth. Rivera and Currais (1999a, 1999b), and Beraldo et al. (2005) use health expenditures as a share of GDP in OECD countries and report a statistically significant impact of health expenditures on growth. Most of the empirical studies that examine government health expenditure find a negative or not significant effect on growth. One study that supports a positive significant effect of government health expenditure on growth is Cooray (2009).

Given the heterogeneity presented in the empirical literature as discussed above, it is difficult to draw a general conclusion on the growth effect of government education or health expenditure. This study therefore aims to revisit the question whether government expenditure on education or health stimulates long-run economic growth using meta-analysis.

\section{Data and Methodology}

\subsection{Data}

We draw on guiding principles proposed by the meta-analysis of economics research-network (MAER-Net), which reflects transparency and the 'best practices' in meta-analysis (Stanley et al., 2013). To identify relevant studies that examine the relationship between government expenditure on education or health (GEH) and growth, we search for journal articles and working papers in five major electronic databases - EconLit, Business Source Compete, Google Scholar, JSTOR and ProQuest. We use various keywords for GEH and growth ${ }^{3}$. In

\footnotetext{
${ }^{3}$ Keywords for GEH include education expenditure, health expenditure, human capital, health spending, education spending. Keywords for growth include GDP, economic growth, gross domestic product, economic development.
} 
addition, we also search through the references of related studies on GEH and growth to ensure that our meta-analysis includes all relevant studies.

We adopt the following criteria to determine studies that we include in our metaanalysis. 1) We include only empirical studies that examine the direct effect of GEH on growth. Thus, studies that examine measures of education other than government education expenditure, such as years of education and literacy rate, among others, are excluded. Similarly, studies that examine the impact of health using measures other than government health expenditure are also excluded. 2) Government education or health expenditure must be an independent variable and must be measured as a proportion of GDP. 3) The growth rate of GDP must be the dependent variable. Therefore, we exclude studies that use the level and/or growth rate of human capital expenditure, and also those that use GDP level instead of GDP growth rate.

Therefore, from an empirical perspective, we only consider empirical studies that adopt some variant of the following growth model, and examine the GEH-growth relationship.

$$
g_{i t}=\alpha_{0}+\alpha_{1} G_{i t}+\sum_{j} \alpha_{j} z_{j, i t}+\varepsilon_{i t}
$$

where $g$ is the growth rate of per-capita GDP and $G$ is the share of government expenditure to GDP. $z_{j}$ is a set of control variables often used in the economic growth literature, and are theoretically supported such as initial level of per-capita GDP, and investment in human or physical capital, among others. The $i$ and $t$ subscripts represents institutional/country and time dimensions, respectively. Specifications of this kind have been widely used in the empirical growth literature. 
Lastly, to allow for comparability of studies, we calculate partial correlation coefficients. For studies that satisfy criteria (1) to (3) above but do not report relevant statistics to allow for the calculation of partial correlation coefficients are excluded as well.

Following the above criteria, we find 31 relevant studies with 306 estimates which are included in this meta-analysis. Table 1 presents an overview of these 31 studies in terms of their simple and fixed effect weighted means, and the corresponding number of estimated extracted from each primary study.

\subsection{Partial Correlation Coefficient}

To ensure a meaningful comparison of studies, we first calculate partial correlation coefficients (PCCs) that measure the impact of government education or health expenditure on growth while holding other factors constant. Given that different factors are held constant in different primary studies, and in some cases, all relevant covariates are not controlled for in regressions, PCCs may be biased. This also leads to heterogeneity in reported estimates. However, this does not render PCCs irrelevant as we examine in our meta-regressions whether control variables used by primary studies affect reported estimates. Based on Greene (2011), we calculate PCCs directly from primary study regression outputs using equation (1). We also calculate corresponding standard errors using equation (2).

$$
r_{i}=\frac{t_{i}}{\sqrt{t_{i}^{2}+d f_{i}}}
$$

and

$$
S E_{r i}=\sqrt{\frac{1-r_{i}^{2}}{d f_{i}}}
$$


where $r_{i}$ and $S E_{r i}$ are the PCC and corresponding standard errors to be calculated from individual studies. $t_{i}$ and $d f_{i}$ are the $t$-statistic and degrees of freedom that correspond with each estimates reported in the primary studies.

\subsection{Meta-analysis: Tools and Methods}

In order to understand and have a clear overview of the evidence base on the GEH-growth relationship, we calculate fixed effect weighted averages for the estimates extracted from the primary studies. We use fixed effect weighted averages because they are more reliable than simple means, and are also less affected by publication bias compared to random effect weighted averages (Henmi and Copas, 2010; Stanley, 2008; Stanley and Doucouliagos, 2014). In addition, with the inverse of the variance used as weight, fixed effect weighted averages assign higher weights to more precise estimates, and lower weights to less precise ones. The fixed effect average $\left(\bar{X}_{F E}\right)$ is calculated using equation (3) below:

$$
\bar{X}_{F E}=\frac{\sum r_{i j}\left(\frac{1}{S E_{r i j}^{2}}\right)}{\sum \frac{1}{S E_{r i j}^{2}}}
$$

where $r_{i j}$ is the estimated $i$ th PCC in study $j$, and $S E_{r i j}^{2}$ is the corresponding variance.

Table 1 presents the fixed effect weighted averages. 29 studies with a total of 237 estimates report on the relationship between government education expenditure and growth. Based on the fixed effects weighted averages, we find that 85 estimates ( $35.86 \%$ of total estimates) are statistically insignificant. 128 estimates (54.01\% of total estimates) are positive and significant, whereas the remaining 24 estimates $(10.13 \%$ of total estimates) are negative. The overall 
weighted average for all 237 estimates is found to be 0.0828 . This suggests that government education expenditure has a positive effect on growth.

[Table 1]

The effect of government health expenditure on growth is reported by 12 studies with a total of 69 estimates. Of the 69 estimates, 26 estimates (37.58\% of total estimates) are statistically insignificant. Of the remaining 43 estimates that are statistically significant, $39(56.52 \%$ of total estimates) are negative, while the remaining four estimates (5.80\% of total estimates) are positive. The overall weighted mean of all 69 estimates (-0.0180) indicates a negative effect of government health expenditure on growth.

When we combine government expenditure on education and health (henceforth the combined government human capital expenditure), the overall weighted average for all 306 estimates is given as 0.0535 . Hence, we conclude that, based on our fixed effect weighted averages, there is a positive effect of the combined government human capital expenditure on growth.

Based on the guidelines presented by Doucouliagos $(2011)^{4}$, the overall weighted averages for explaining the effects of government health expenditure and the combined government human capital expenditure on growth, i.e., -0.0180 and 0.0535 , respectively, represent small effect with very little economic significance. However, if the reported weighted averages are fraught with issues of publication bias, they cannot represent genuine measures of the effects on growth (De Dominicis et al., 2008; Doucouliagos and Stanley, 2009). Thus, in the next section, to investigate the robustness of our fixed effect weighted averages, we examine if the reported estimates are tainted with publication bias.

\footnotetext{
${ }^{4}$ Cohen (1988) indicates that an effect size represents small effect if its absolute value is less than 0.10 , medium effect if it is 0.25 and over, and large if it is greater than 0.4. However, Doucouliagos (2011) indicates that the application of Cohen's guidelines to partial correlation coefficients understate the economic significance of empirical effect and thus, he proposes that effect size greater than 0.07 and 0.33 represent a 'medium' and 'large' effects, respectively.
} 


\subsubsection{Detecting and Correcting Publication Bias}

Publication selection bias occurs when authors, reviewers and editors select statistical significant results consistent with theory to justify model selection (Stanley, 2008). To examine if the reported estimates are subject to publication bias, we first present funnel plots which show the relation between PCCs and their precision $\left(1 / S E_{r i}\right)$. In the absence of publication bias, funnel plots should resemble a symmetric funnel and thus, an asymmetric funnel plot suggests publication bias (Stanley and Doucouliagos, 2010). Figures 1 to 3 are funnel plots of the estimated effected sizes of the various government expenditures on growth against their precision.

[Figures 1 to 3]

A visual inspection of the funnel plots reveals not much signs of asymmetries with regards to our reference lines. This suggests that publication bias may not be an issue in the GEH-growth literature. However, although funnel plots may be useful, they are only indicative and do not provide definite evidence on the presence or absence of bias. In addition, they are not very useful in determining the magnitude and significance of bias. Therefore, to thoroughly examine issues of publication bias, we adopt a more formal analysis - the precision effect test (PET) and the funnel asymmetry test (FAT). PET/FAT analyses (Egger et al, 1997; Stanley, 2008) are able to help establish if reported estimates are tainted with publication bias and whether they represent genuine effect beyond bias. Stanley (2008) demonstrates that the weighted least squares (WLS) bivariate model in equation (4) can be used to test for both publication bias (FAT) and for genuine effect beyond bias (PET):

$$
t_{i}=\alpha_{0}+\beta_{0}\left(\frac{1}{S E_{r i}}\right)+\varepsilon_{i}
$$


where $t_{i}$ is the t-value and $1 / S E_{r i}$ is the precision. $H_{0}: \alpha_{0}=0$ and $H_{0}: \beta_{0}=0$ are tests for the absence/presence of publication bias (FAT) and genuine effect (PET), respectively. Hence, at conventional levels, there is evidence of bias if $\alpha_{0}$ is statistically significant, and evidence of genuine effect if $\beta_{0}$ is statistically significant.

Given that several observations are clustered within the primary studies, the data used in this meta-analysis are characterized by an inherent hierarchical structure. Thus, in our case, the estimation of equation (4) with OLS may be erroneous and prone to various criticisms. This is because the assumption that the reported effect sizes are independently distributed may be flawed. Some researchers resort to the use of single effect size estimates for each primary study. However, this approach is often criticized on the grounds of subjectivity, given that the criteria used in the selection of that single estimate is considered subjective. In addition, this approach does not represent the overall evidence base as several effect size estimates are excluded.

Therefore, we adopt the multilevel linear models [MLM] (Goldstein, 1995) which is a more plausible approach to estimate equation (5). This approach has been used in various metaanalyses to deal with the issues of data dependence (see e.g., Alptekin and Levine, 2012; Bateman and Jones, 2003; De Dominicis et al., 2008). Moreover, using results from likelihood ratio tests, which compare MLM to the standard OLS, we confirm that the MLM in the case of our dataset is preferred to OLS.

$$
t_{i j}=\alpha_{0}+\beta_{0}\left(\frac{1}{S E_{r i j}}\right)+v_{j}+\varepsilon_{i j}
$$

where $t_{i j}$ is $i$ th t-value in study $j$, and $1 / S E_{r i}$ is the, precision. $\varepsilon_{i j}$ is the normally distributed estimate-level error term, whereas $v_{j}$ is the study-level error term which captures betweenstudy variations. We assume study level fixed-effects (Stanley and Doucouliagos, 2012), and estimate equation (5) as a multilevel linear model (MLM). 
Table 2 presents results from our PET-FAT analysis. Panel 1 presents results for the government education expenditure-growth relationship. Results suggest a positive association, with no evidence of publication bias. The effect size is 0.0768 , which represents a small empirical effect.

\section{[Table 2]}

For government health expenditure, PET/FAT results as shown in Panel 2, reveal a statistically insignificant association between government expenditure on health and economic growth. However, with regards to the combined government education and health expenditure, results from Panel 3 show that there is a positive effect on growth with no evidence of publication bias. Thus, based on PET/FAT results, we can conclude that there is a positive effect of the combined government human capital expenditure on growth, with no evidence of bias, which is consistent with evidence presented by the fixed effect weighted averages.

\subsubsection{Addressing Heterogeneity}

PET/FAT analyses do not account for moderating variables as they assume differences among reported estimates are due to sampling error alone. However, this is not the case in the GEHgrowth literature. Furthermore, it is important to explore issues of heterogeneity in the literature in order to identify the factors that cause variations in reported estimates. Thus, in what follows, we identify factors of heterogeneity among reported estimates, known as moderator variables, and conduct a multivariate meta-regression analysis (MRA) that examines the extent to which these factors affect the GEH-growth relationship.

We extend equation (5) to yield a model which accounts for both heterogeneity and publication bias. Thus, equation (6) is an extension of equation (5), and allows for the inclusion of moderator variables. 


$$
t_{j i}=\alpha_{0}+\beta_{0}\left(\frac{1}{S E_{j r i}}\right)+\sum \beta_{k} \frac{\left(Z_{k i}\right)}{S E_{j r i}}+v_{i j}+\varepsilon_{i j}
$$

Here, $Z_{k i}$ is a vector of moderator variables that may account for variations in the GEH-growth relationship evidence base. We estimate equation (6) to account for model heterogeneity and account for data dependency. As done in the case of the PET/FAT analysis, the MLM estimation is used here also. In addition, we present two specification/model types - general model and the general-to-specific model. The more general specification contains all relevant dimensions and factors that are likely to affect the GEH-growth relations. The specific model, however, is obtained by excluding, one at a time, the highly insignificant variables (i.e., those with the highest p-values) until statistical significance is attained for included moderator variables. This is done to reduce model complexity, and deal with issues of over-determination and multicollinearity ${ }^{5}$.

Moderator variables are systematic variations in primary studies that can potentially affect the nature of reported estimates. Given the GEH-growth literature, our choice of moderator variables in this meta-analysis is informed by dimensions such as econometric specifications, theoretical reasoning, data differences and other difference in primary studies. Thus, the regression with the highest number of moderator variables (i.e., both government education and health expenditures combined) captures all these dimensions. Relatively fewer moderator variables are included in regressions for government education expenditure only (Table 3 Panel A) and government health expenditure only (Table 3 Panel B), given that they include fewer studies with relatively less variations compared to the combined estimates from both categories (i.e., the combined government human capital expenditure, Table 3 Panel C).

\footnotetext{
${ }^{5}$ See Campos et al. (2005) for a review of the literature on general-to-specific modelling.
} 
Table A1 presents a description and summary statistics of the moderator variables used in our MRA. MRA results are reported in Tables 3.

\subsubsection{Data Characteristics}

We first investigate if the GEH-growth nexus is time variant. Thus, for the MRA with the largest sample size (Table 3 Panels A and C), we include three dummy variables to chapter the 'recentness' of data used by primary studies. The first dummy variable captures studies that use data starting from 1980, while the second captures studies that include data starting from the 1990s and the last starting from 2000s. Studies that use dataset with the starting year earlier than 1980 are excluded as base $^{6}$. From Table 3, based on the results, we find statistically significant coefficient for the time dummies, suggesting that the GEH-growth nexus is time variant. Specifically, we find that, as opposed to studies that do not, studies that use data from 1990 and beyond tend to report less positive effects of the effect of education expenditure on growth. The opposite is however observed in Panel $\mathrm{C}$ which combines estimates from both education and health expenditure studies. On the other hand, studies that use newer dataset $(2000+)$ and report on the health expenditure-growth association tend to report less adverse effects compared to those that do not.

[Table 3]

We further examine if the GEH-growth relationship is affected by sample type. Various studies have argued that expenditures on human capital investment, especially education, affect growth differently in developed and less developed countries (LDCs). Thus, we include a dummy for country type to examine if reported estimates are different based on the sample used. We include a dummy for LDCs and another dummy for studies that reported estimates on OECD

\footnotetext{
${ }^{6}$ For MRA results reported in Panel B, variables not included in regressions are used as base.
} 
countries to represent developed countries. Our results show that the dummies for country types across all panels are statistically insignificant. However, from Panel B, we find that the dummy for OECD is negative and significant for both the general and specific models. This suggests that studies that use data on OECD countries, as opposed to does that do not, tend to report more adverse effects of health expenditures on growth.

\subsubsection{Theoretical Models and Econometric Specification}

Econometric specifications used in primary studies are often based on certain underlying theoretical models. The GEH-growth relationship is likely to be affected by the underlying theoretical models which inform econometric model specifications. We examine if underlying theoretical models affect the GEH-growth association. We control for studies that base their specifications on endogenous growth models while excluding studies that adopt the Solowtype growth model as base. The results show that studies that adopt specifications based on endogenous growth model report more negative effects of education expenditure on growth, compared to those that do not. This is also the case for the association between health expenditure and growth.

The first dimension of econometric specification that we capture is the length of timeperiod over which variables are averaged. The length of time over which variables are averaged in primary studies can potentially affect reported estimates. A number of arguments are usually presented in favour of data averaging. For instance, averaging over a period equal to the business cycle (usually five years) eliminates business cycle effects, especially if primary studies do not include measures of business cycle (e.g., output gap) in their models. Also, estimates based on data averaged over a period of 5 years or more can be interpreted as medium- to long-run effects as opposed to short-run effects. A common practice in the literature is the use of 5-years averaging. Some studies also use averaging periods greater than 
or less than five years. In our MRA, we control for time horizon to verify if the effect of human capital expenditure on growth is larger when the data period is averaged over periods equal to or longer than five years. Thus, we include a dummy for studies where data is average over a period of five year or more, and exclude other studies as base. We find that that studies that use data averaging for periods equal to or greater than five years tend to report less adverse effects of education expenditure on growth. However, for the association between health expenditure and growth primary studies that take averages of data over periods equal to or longer than five years tend to report more adverse effects, as opposed to those that do not.

Next, we compare the differences reported in estimates presented by cross-section and panel data estimation. Some studies tend to rely on cross-section data averaged over long periods. However, cross-section estimations usually overlook country-specific fixed effects that may capture country-specific differences in cross-country regressions. Thus, in the presence of fixed-effects, cross-section estimates may be biased. Panel-data estimations on the other hand are able to address this source of bias by purging the country-specific fixed effects and focusing on temporal variations in the data. Therefore, we include a dummy that captures studies that use cross-section data and compare this with panel data. From Panel A, we find that the use of cross-section data (as opposed to panel data) is associated with less adverse effects of education expenditures on growth. This suggests that the use of cross-section data is likely to be a source of positive bias in the evidence base, and therefore it is likely that the positive effect of government education expenditures on growth in the policy debate may be based on incorrect inference. This result is also true in Panel C. We also control for studies that use panel data and adopt data averaging of five years or more. The coefficient for this dummy is mainly insignificant except for a positive effect observed in column 6 .

We also control for the covariates used in primary studies. In economics, it is general knowledge that the exclusion and/or inclusion of certain control variables can affect regression 
coefficients. This extends to the government expenditure-growth literature as well. For instance, studies such as Levine and Renelt (1992) present discussions on the issue and argue that major growth determinants include investment share of GDP, population growth rate and initial GDP, among others. Other key determinants of growth discussed in the literature include taxes. Specific to the GEH-growth literature, the role of institutions and governance, political stability (or instability) and life expectancy have been hypothesized as relevant factors that can affect growth. We control for studies that use all the above mentioned variables in order to examine if the exclusion/inclusion of such variables from primary study regressions affect reported research findings.

Overall, results indicate that the inclusion/exclusion of certain explanatory variables affect the nature of reported estimates. Specifically, we find that studies that control for population growth rate, political instability and government quality (as opposed to those that do not), and examine the impact of government education expenditure on growth are predisposed to report more adverse effects. This finding is also true for the effect of the combined government human capital expenditure on growth (Panel C). Dummy for studies that control for private investment is statistically insignificant in the government education expenditure specification, but negative in the other two estimations (Panels B and C). Similarly, the tax dummy shows a negative effect in the education expenditure specification (Panel A) but is statistically insignificant in the other specifications. Thus, overall, while consistency is not observed for these dummy variables, it is obvious that the inclusion or exclusion of key growth determinants can significantly alter the nature of reported estimates.

Lastly, OLS estimates are inconsistent and biased in the presence of endogeneity, making inferences misleading. Thus, studies on the relationship between government expenditures and economic growth control for endogeneity using instrumental variable (IV) techniques. In this tradition, a number of primary studies that examine the GEH-growth 
association address endogeneity by adopting various IV techniques instead of or in addition to non-instrumented methods such as OLS. Therefore, in our MRA, we control for studies that control for endogeneity as opposed to those that do not. This allows us to examine if the control for endogeneity yields systematically different effect-size estimates compared to other estimation methods that do not. We find that the dummy for studies that control for endogeneity is statistically insignificant.

\subsubsection{Publication Characteristics}

With regards to publication characteristics, we first control for publication type, and examine if the estimates reported in journal articles are different compared to those reported in working papers and book chapters. We include a dummy for studies published in journals, and exclude working papers and book chapters as base. Results mainly suggest that publication type does affect the nature of reported estimates. Specifically for education (Panel A) and health (Panel B) expenditure specifications, we find that journal articles as opposed to book chapters or working papers tend to report more positively on growth.

We also examine if the GEH-growth association varies with the publication outlet used by primary studies. Therefore, we control for publication outlet by including a dummy for highranked journals. ${ }^{7}$ Except for the government health expenditure-growth MRA (Panel B) where the dummy for journal rank is not significant, results show that high-ranked journals (as opposed to low-ranked journals) are predisposed to reporting more adverse effects.

Lastly, we also control for publication year in order to examine if the reported estimates on the GEH-growth nexus change overtime in publications. Given that richer dataset and newer econometric techniques emerge over time, more studies are published to challenge the status

\footnotetext{
7 The Australian Business Dean's Council (ABDC) and the Australian Research Council (ARC) present classifications for journal quality. Journals are ranked in descending order of quality as A*, A, B and C. Thus, we introduce a dummy for A* and A ranked journals (high quality) in our MRA, and use other ranks as base.
} 
quo. Thus, it is worthwhile to examine if the nature of reported estimates change as newer publications emerge. We include a dummy for studies that are published in the year 1990 and beyond, and those that are published in the year 2000 and beyond. We exclude other studies as base. In the education expenditure specification, results suggest that newer studies tend to report more positive association between education expenditure and growth. Conflicting results are observed for Panels B and C. We find that the dummy for publications in the year 1990 and beyond is negative in Panel B but positive in Panel C.

\subsubsection{Conditional Effect on Growth/Common Research Practices}

The net growth effect of the various measures of human capital expenditures on growth, in the context of the MRA, is conditional on moderator variables. Thus, we zoom in on various practices often adopted by researchers to examine what the net effect is on growth. With regards to studies that examine the effect of government education expenditure on growth, we first consider studies that use OECD data, control for endogeneity and also adopt some variant of the endogenous growth model to inform their empirical model specification. In this category, we find a conditional effect of 0.2151 of government education expenditure on growth. Second, we find a conditional effect of 0.4134 for studies that examine the effect of education expenditure on growth applying methods that control for endogeneity on OECD data, and also control for taxes and initial GDP in their regressions. Third, for studies that use cross-section data on LDCs and control for taxes, we find a conditional effect of 0.3229. Lastly, for the education expenditure-growth relationship, we examine the conditional effect of relatively new studies published with focus on LDCs. We note that the conditional effect of education expenditure on growth for studies that use 5-years or more data averaging on LDCs data and are published after 1999 is 0.2189 . On average, it is observed that the conditional effect of 
government education expenditure on growth is stronger for developed countries (measured by the OECD) than LDCs.

For the association between government health expenditure and growth, first, we examine the effect of studies that examine OECD data and develop an empirical model informed by the endogenous growth model and are published in high-ranking journals. The conditional effect for this category is observed to be -0.3208 . Similarly, for studies that use OECD data and control for initial GDP and taxes in their regressions, we find a conditional effect of -0.2211 . Third, for studies that use data on LDCs and control for governance quality and taxes, we find a conditional effect of -0.4119 . Lastly, a conditional effect of -0.4942 is reported for studies that examine the health expenditure-growth relationship, and use 5-years or more data averaging on LDCs data and are published after 1999.

Overall, taking into account MRA results and our conditional effects on growth which represent the measure of genuine effects that control for both publication bias and heterogeneity, we can conclude that government education expenditures have a positive effect on growth, whereas government health expenditure impacts growth negatively. Drawing on inferences made by both Cohen (1988) and Doucouliagos (2011), these effects are not trivial, and thus present meaningful and practical economic significance.

\section{Discussions and Conclusions}

Based on 306 estimates drawn from 31 primary studies, we conduct a meta-analysis that examines the effect of government education or health expenditure (GEH) on economic growth. Specifically, we examine the following three hypotheses: (H1) government education expenditure as a proportion of GDP promotes growth, $(\mathrm{H} 2)$ government health expenditure as a proportion of GDP promotes growth, and (H3) the combined government human capital 
expenditure (i.e., the combined government expenditure on education and health) as a proportion of GDP promotes growth. Based on our results, the following major conclusions emerge.

The results from fixed effects weighted averages, bivariate precision effect and funnel asymmetry tests (PET/FAT), and multivariate meta-regression analysis (MRA) all indicate that there is a positive association between government education expenditure and growth. Thus, whether or not publication bias and/or moderator variables have been controlled for, the effect of government education expenditure on growth remains positive. For the association between government health expenditure and growth, we find a negative effect. This is evident from the fixed effect weighted averages and also MRA results after controlling for relevant moderator variables. With regards to the combined government human capital expenditure, we find that all meta-analysis techniques - fixed effect weighted averages, PET/FAT and MRA - show a positive effect on growth.

Based on these findings, it is obvious that $(\mathrm{H} 1)$ and $(\mathrm{H} 3)$ are supported, but $(\mathrm{H} 2)$ is rejected. We also find that the GEH-growth relationship is not fraught with issues of publication selection bias. This finding is consistent across the various measures of government expenditures of human capital used in this study. MRA results also show that $(\mathrm{H} 2)$ is not supported for the OECD countries, indicating that negative effects of government health expenditure on growth are more pronounced for the OECD countries in the literature.

Our MRA results provide some important implications. In general, government expenditure on human capital investment may not always increase long-run growth, and in particular, government health expenditure tends to reduce growth especially in developed countries. Possible explanations are government health expenditure crowds out other factors which contribute to growth, or public resources are allocated inefficiently or inequitably in the health sector, or the quality of government health expenditure is low overall. 
The crowding-out effect and the welfare losses from tax distortions in the health sector tend to occur in developed countries due to their huge and rising shares in the government health expenditure-GDP ratios. In fact, according to OECD health data, governments of most OECD countries shoulder the lion's share of health care costs. The share of government expenditure allocated to health increased in most countries, rising from an average of $12 \%$ in 1990 to $16 \%$ in 2008. Similarly, public expenditure on health in the EU grew faster than GDP and total government expenditure for most of the period 1996 to 2011, while most categories of government expenditure (e.g., education) maintained roughly constant shares in total expenditure between the same periods of time. Public expenditure on health in the EU is now the second highest government expenditure share with about $15 \%$, after social protection with about 40\% (see OECD health data, Eurostat data and WHO Health Data).

Therefore, governments in many OECD countries will have to cut spending in other areas, or raise taxes to sustain their healthcare systems and to reduce their budget deficits. When increased public health expenditure crowds out public and private resources devoted to productive activities (such as $\mathrm{R} \& \mathrm{D}$, investment in physical capital stock and education), an increase in public health expenditure may adversely affect the composition of government expenditure and economic growth. ${ }^{8}$ In addition, distortionary taxes tend to distort saving decisions and lower growth when taxes are sufficiently large (see e.g., Barro, 1990). Thus, sufficiently high government health expenditures financed by distortionary taxes in developed countries tend to aggravate distortions, reduce the efficiency of resource allocation, crowd out productive activities, and retard long-run economic growth.

Furthermore, due to rapid population ageing in developed countries, a large fraction of public health expenditure is devoted to the elderly population over 65. A larger population of elderly in a developed country implies a greater demand for public health care and thus, higher

\footnotetext{
${ }^{8}$ Devarajan et al. (1996) show that changes in the composition of government spending affects a country's economic growth.
} 
government health expenditure because elderly people often require costly medical treatment due to multi-morbidities and chronic illnesses. Therefore, higher government health expenditure may lead to improvements in life expectancy without accompanied by improvements in health status and human capital formation. Also, although it has been established that health allows for a more effective performance that increases productivity (Grossman, 1972), considering the elderly population who are not part of the active work force, investment into health does not necessarily promote productivity.

Another possible explanation for a negative growth impact of government health expenditure in developed countries is that governments may not be paying enough attention to improve the efficiency and quality of public health expenditure. Increasing expenditure alone is insufficient to produce good health outcome and lead to an increase in human capital stock. For example, if public investments in medical science help people live longer, but with poor mobility, there will be less chance for these people to work, and therefore there could be a fall in labour force participation rate and economic growth. Thus, high quality and effective public health care are essential to achieve substantial improvement in average health status so as to improve the value for money used in the provision of health services. ${ }^{9}$

Overall, governments in developed countries are facing many complicated issues in the health sector. These issues include administrative complexity, aging of the population, high prices for medical inputs such as drugs and the services of specialist physicians, expensive medical technology, waiting lists, chronic disease burden, supply and utilization rates, access to care, resource allocation within the health sector, among many others. Thus, increasing public resources to health sector alone may be insufficient for governments to improve health status of a population and achieve faster accumulation of human capital and thus, economic growth.

\footnotetext{
${ }^{9}$ According to Anderson and Frogner (2008), there is scant evidence that the United States gets better value for its higher health care spending.
} 
With regards to systematic heterogeneity in the GEH-growth literature, we find that primary study characteristics such as data type, period of data averaging, publication outlets used and variables included in econometric specification contribute to variations in reported effect sizes.

Concerning variables included in econometric specifications, MRA results indicate statistical significance for the dummies included for variables such as initial GDP, population, private investment, life expectancy, political instability and government quality. This suggests the growth impact of GEH may change when these variables are omitted in primary study regressions since they are key growth determinants. Thus, the exclusion of such variables could lead to biased results in the GEH-growth literature. Hence, it would be good practice for researchers to include key regressors in regressions with a view to minimize the risk of model specification bias and the additional heterogeneity resulting from such biases.

A number of suggestions emerge for future research. First, except for the introduction of dummies to capture the effect of country types, we are not able to thoroughly examine our hypotheses for country types owing to data constraints ${ }^{10}$. In the future, given an increase in the number of primary studies that examine the GEH-growth association, a course of future research would be to re-examine this association by splitting meta-observations to capture country types. Beyond the use of a dummy variable to capture the effect of country types, a thorough investigation which involves a separate meta-analysis for LDCs and developed countries can help shed light on the possible causes of heterogeneity in the literature examining each country type.

Second, with arguments that there are diminishing effects of human capital expenditure on growth, future studies need to examine empirically if the growth effect of government expenditure on human capital is non-linear. Our meta-analysis reveals that very few studies have examined the issue of non-linearity.

\footnotetext{
${ }^{10}$ Splitting our sample to conduct separate MRAs for LDCs and developed countries was not possible because the sample size in each category was not sufficiently large.
} 
Lastly, a few studies are excluded from our meta-analysis because relevant statistics needed for the calculation of partial correlation coefficients are not reported. It is in the best interest of future research that standards be set regarding the inclusion of relevant statistics such as $\mathrm{t}$ values and/or standard errors in primary studies. 


\section{References}

Afonso, A., \& Jalles, J. T. (2013). Fiscal composition and long-term growth. Applied Economics, 46(3), 349-358.

Aghion, P., Caroli, E., \& García-Peñalosa, C. (1999). Inequality and Economic Growth: The Perspective of the New Growth Theories. Journal of Economic Literature, 37(4), 1615-1660.

Alptekin, A., \& Levine, P. (2012). Military expenditure and economic growth: A meta-analysis. European Journal of Political Economy, 28(4), 636-650.

Anderson, J., \& Frogner, B. (2008). Health spending in OECD countries: obtaining value per dollar. Health Affairs, 27, 1718-1727.

Baldacci, E., Clements, B., Gupta, S., \& Cui, Q. (2004). Social Spending, Human Capital, and Growth in Developing Countries: Implications for Achieving the MDGs. IMF Working Paper No. $04 / 217$.

Baldacci, E., Clements, B., Gupta, S., \& Cui, Q. (2008). Social Spending, Human Capital, and Growth in Developing Countries. World Development, 36, 1317-1341.

Barro, R. (2013). Health and Economic Growth. Annals of Economics and Finance, 14(2), 329-366.

Barro, R., \& Lee, J.-W. (1993). International Comparisons of Educational Attainment. Journal of Monetary Economics, 32, 363-394.

Barro, R. J. (1989). Economic Growth In A Cross Section Of Countries: University of Rochester Center for Economic Research (RCER).

Barro, R. J. (1991). Economic Growth in a Cross Section of Countries. The Quarterly Journal of Economics, 106(2), 407-443.

Barro, R. J. (1996). Determinants of Economic Growth: A Cross-Country Empirical Study. NBER Working Paper No. 5698.

Barro, R. J. (1996). Three Models of Health and Economic Growth. Harvard University. Cambridge, MA.

Barro, R. J., \& Sala-i-Martin, X. (1995). Economic Growth Cambridge, MA: MIT Press.

Barro, R. J., \& Sala-i-Martin, X. (2004). Economic Growth, second edition. Cambridge, Massachusetts: The MIT Press.

Bassanini, A., \& Scarpetta, S. (2001). Does Human Capital Matter for Growth in OECD Countries? Evidence from Pooled Mean-Group Estimates. OECD Economics Working Paper No. 282.

Bateman, I., \& Jones, A. (2003). Contrasting conventional with multi-level modelling approaches to meta-analysis: expectation consistency in U.K. woodland recreation values. Land Economics 79(2), 235-258.

Becker, G. S., Murphy, K. M., \& Tamura, R. (1990). Human Capital, Fertility, and Economic Growth. Journal of Political Economy, 98(5), S12-S37.

Benabou, R. (2002). Tax and education policy in a heterogeneous-agent economy: what Levels of redistribution maximize growth and efficiency? Econometrica, 70, 481-517.

Benhabib, J., \& Spiegel, M. M. (1994). The role of human capital in economic development evidence from aggregate cross-country data. Journal of Monetary Economics, 34(2), 143-173.

Benos, N., \& Zotou, S. (2014). Education and Economic Growth: A Meta-Regression Analysis. World Development, 64(0), 669-689.

Beraldo, S., Montolio, D., \& Turati, G. (2005). Healthy, educated and wealthy: is the welfare state really harmful for growth? . Working Papers in Economics 127, Barcelona: Universitat de Barcelona, Espai de Recerca en Economia.

Bils, M., \& Klenow, P. J. (2000). Does Schooling Cause Growth? American Economic Review, 90(5), $1160-1183$.

Blankeanu, W. F. (2005). Public schooling, college subsidies and growth. Journal of Economic Dynamics and Control, 29(3), 487-507.

Blankenau, W. F., Simpson, N. B., \& Tomljanovich, M. (2007). Public Education Expenditures, Taxation, and Growth: Linking Data to Theory. American Economic Review, 97(2), 393-397.

Bloom, D. E., \& Canning, D. (2000). The Health and Wealth of Nations. Science, 287, 1207-1209.

Bloom, D. E., Canning, D., \& Sevilla, J. (2001). The Effect of Health on Economic Growth: Theory and Evidence. NBER Working Paper No. 8587. 
Bojanic, A. N. (2013). The Composition of Government Expenditures and Economic Growth in Bolivia. Latin American Journal of Economics, 50(1), 83-105.

Bose, N., Haque, M. E., \& Osborn, D. R. (2007). Public Expenditure and Economic Growth: A Disaggregated Analysis for Developing Countries. Manchester School, 75(5), 533-556.

Bryant, J. (1969). Health and the Developing World. Ithaca, NY: Cornell University Press.

Campos, J., Ericsson, N., \& Hendry, D. (2005). General-to-specific modeling: an overview and selected bibliography. . FRB International Finance Discussion Paper, (838).

Caselli, F., Esquivel, G., \& Lefort, F. (1996). Reopening the convergence debate: A new look at cross-country growth empirics. Journal of Economic Growth, 1(3), 363-389.

Cassou, S., \& Lansing, K. (2001). Tax reform and public sector investment in human capital.

Castelló-Climent, A. (2008). On the distribution of education and democracy. Journal of Development Economics, 87(2), 179-190.

Castelló-Climent, A., \& Doménech, R. (2008). Human Capital Inequality, Life Expectancy And Economic Growth*. The Economic Journal, 118(528), 653-677.

Cohen, J. (1988). Statistical Power Analysis for the Behavioural Sciences Hillsdale, NJ.

Colombier, C. (2009). Growth effects of fiscal policies: an application of robust modified Mestimator. Applied Economics, 41(7), 899-899.

Cooray, A. (2009). Government Expenditure, Governance and Economic Growth. Comparative Economic Studies, 51(3), 401-418.

Cooray, A. V. (2009). The role of education in economic growth. Proceedings of the 2009 Australian Conference of Economists, 1-27.

Dalic, M. (2013). Fiscal policy and growth in new member states of the EU: a panel data analysis. Financial Theory and Practice, 37(4), 335-360.

Dao, M. Q. (2012). Government expenditure and growth in developing countries. Progress in Development Studies, 12(1), 77-82.

De Dominicis, L., Florax , R., \& Groot, H. (2008). A meta-analysis on the relationship between income inequality and economic growth. Scottish Journal of Political Economy, 55(5), 654682.

Devarajan, S., Swaroop, V., \& Zou, H.-f. (1996). The Composition of Public Expenditure and Economic Growth. Journal of Monetary Economics, 37(2), 313-344.

Diamond, J. (1998). Fiscal indicators for economic growth: The Government own saving concept reexamined. Journal of Public Budgeting, Accounting \& Financial Management, 9(4), 627-651.

Doucouliagos, H. (2011). How Large is Large? Preliminary and relative guidelines for interpreting partial correlations in economics. Deakin University, School of Accounting, Economics and Finance Working Paper Series (5).

Doucouliagos, H., \& Stanley, T. (2009). Publication selection bias in minimum-wage research? A metaregression analysis. British Journal of Industrial Relations 47(2), 406-428.

Dunne, J. P., \& Mohammed, N. A. L. (1995). Military Spending in Sub-Saharan Africa: Some Evidence for 1967-85. Journal of Peace Research, 32(3), 331-343.

Easterly, W., \& Rebelo, S. (1993). Fiscal policy and economic growth: An empirical investigation. Journal of Monetary Economics, 32(3), 417-458.

Eckstein, Z., \& Zilcha, I. (1994). The effects of compulsory schooling on growth, income distribution and welfare. Journal of Public Economics, 53, 339-359.

Egger, M., Smith, D., Schneider, M., \& Minder, C. (1997). Bias in meta-analysis detected by a simple, graphical test. BMJ, 315, 629 - 634 .

Glaeser, E. L., La Porta, R., Lopez-de-Silanes, F., \& Shleifer, A. (2004). Do Institutions Cause Growth? Journal of Economic Growth, 9(3), 271-303.

Glomm, G., \& Ravikumar, B. (1992). Public versus private investment in human capital: endogenous growth and income inequality. Journal of Political Economy, 100, 818-834.

Glomm, G., \& Ravikumar, B. (1997). Productive Government Expenditures and Long-Run Growth. Journal of Economic Dynamics and Control, 21(1), 183-204.

Glomm, G., \& Ravikumar, B. (1998). Flat-Rate Taxes, Government Spending on Education, and Growth. Review of Economic Dynamics, 1(1), 306-325.

Goldstein, H. (1995). Multilevel Statistical Models (2nd ed.). London: Edward Arnold.

Greene, W. (2011). Econometric Analysis 7 edition. New Jersey: Prentice Hall. 
Grossman, M. (1972). On The Concept Of Health Capital And The Demand For Health. Journal of Political Economy, 80, 223-255.

Hansson, P., \& Henrekson, M. (1994). A new framework for testing the effect of government spending on growth and productivity. Public Choice, 81(3-4), 381-401.

Hanushek, E. A., \& Woessmann, L. (2008). The Role of Cognitive Skills in Economic Development. Journal of Economic Literature, 46(3), 607-668.

Henmi, M., \& Copas, J. B. (2010). Confidence intervals for random effects meta-analysis and robustness to publication bias. Stat Med, 29(29), 2969-2983.

Islam, N. (1995). Growth Empirics: A Panel Data Approach. The Quarterly Journal of Economics, 110(4), 1127-1170.

Jack, W. (1999). Principles of Health Economics for Developing Countries. Washington DC: World Bank Institute Development Studies.

Jamison, D., Lau, L., \& Wang, J. (2004). Health's contribution to economic growth in an environment of partially endogenous technical progress, disease control priorities project. Working Paper No 10, Bethesda, Maryland: Fogatry International Centre, NIH.

Kaganovich, M., \& Zilcha, I. (1999). Education, social security, and growth. Journal of Public Economics, 71, 289-309.

Keller, K. R. I. (2006). Education Expansion, Expenditures per Student and the Effects on Growth in Asia. Global Economic Review, 35(1), 21-42.

Kelly, T. (1997). Public Expenditures and Growth. Journal of Development Studies, 34(1), 60-84.

Kneller, R., Bleaney, M. F., \& Gemmell, N. (1999). Fiscal Policy and Growth: Evidence from OECD Countries. Journal of Public Economics, 74(2), 171-190.

Knight, M., Loayza, N., \& Villanueva, D. (1993). Testing the Neoclassical Theory of Economic Growth: A Panel Data Approach. Staff Papers - International Monetary Fund, 40(3), 512541.

Krueger, A. B., \& Lindahl, M. (2001). Education for Growth: Why and For Whom? Journal of Economic Literature, 39(4), 1101-1136.

Landau, D. (1983). Government Expenditure and Economic Growth: A Cross-Country Study. Southern Economic Journal, 49(3), 783-792.

Landau, D. (1986). Government and Economic Growth in the Less Developed Countries: An Empirical Study for 1960-1980. Economic Development and Cultural Change, 35(1), 35-75.

Landau, D. L. (1997). Government expenditure, human capital creation and economic growth. Journal of Public Budgeting, Accounting \& Financial Management, 9(3), 467-467.

Levine, R., \& Renelt, D. (1992). A Sensitivity Analysis of Cross-Country Growth Regressions. The American Economic Review, 82(4), 942-963.

Lillard, L. A., \& Weiss, Y. (1997). Uncertain Health and Survival: Effects on End-of-Life Consumption. Journal of Business \& Economic Statistics, 15(2), 254-268.

Lipset, S. (1960). Political Man: The Social Bases of Politics. New York: Doubleday.

Lucas, R. E. (1988). On the mechanics of economic development. Journal of Monetary Economics, 22(1), 3-42.

Mankiw, N. G., Romer, D., \& Weil, D. N. (1992). A Contribution to the Empirics of Economic Growth. The Quarterly Journal of Economics, 107(2), 407-437.

Miller, S. M., \& Russek, F. S. (1997). Fiscal Structures and Economic Growth: International Evidence. Economic Inquiry, 35(3), 603-613.

Miyakoshi, T., Tsukuda, Y., Kono, T., \& Koyanagi, M. (2010). Economic Growth and Public Expenditure Composition: Optimal Adjustment Using the Gradient Method. Japanese Economic Review, 61(3), 320-340.

Mo, P. H. (2007). Government Expenditures and Economic Growth: The Supply and Demand Sides. Fiscal Studies, 28(4), 497-522.

Moretti, E. (2004a). Estimating the social returns to higher education: evidence from longitudinal and repeated cross-section data. Journal of Econometrics, 121, 175-212.

Moretti, E. (2004b). Workers' education, spillovers, and productivity: evidence from plant-level production functions. American Economic Review, 94, 656-690.

Mulligan, C. B., \& Sala-I-Martin, X. (1993). Transitional Dynamics in Two-Sector Models of Endogenous Growth. The Quarterly Journal of Economics, 108(3), 739-773. 
Neycheva, M. (2010). Does public expenditure on education matter for growth in Europe? A comparison between old EU member states and post-communist economies. Post Communist Economies, 22(2), 141-141.

Perotti, R. (1996). Growth, income distribution, and democracy: What the data say. Journal of Economic Growth, 1(2), 149-187.

Pritchett, L. (1996). Where Has All the Eduation Gone? The World Bank, Policy Research Working Paper 1581.

Rivera, B., \& Currais, L. (1999a). Economic growth and health: direct impact or reverse causation? . Applied Economics Letters, 6, 761-764.

Rivera, B., \& Currais, L. (1999b). Income variation and health expenditure: evidence for OECD countries. Review of Development Economics, 3, 258-267.

Romer, P. M. (1986). Increasing Returns and Long-Run Growth. Journal of Political Economy, 94(5), 1002-1037.

Rosen, S. (1976). A theory of life earning. Journal of Political Economy, 84, S45-S67.

Schultz, T. W. (1961). Investment in human capital. American Economic Review, 61, 1-17.

Singh, R. J., \& Weber, R. (1997). The Composition of Public Expenditure and Economic Growth: Can Anything Be Learned from Swiss Data? Schweizerische Zeitschrift fur Volkswirtschaft und Statistik/Swiss Journal of Economics and Statistics, 133(3), 617-634.

Smith, J. P. (1998). Socioeconomic Status and Health. The American Economic Review, 88(2), 192196.

Solow, R. (1956). A contribution to the theory of economic growth. Quarterly Journal of Economics, $70(1), 65-94$.

Sorkin, A. (1977). Health Economics in Developing Countries Lexington, MA: Lexington Books.

Stanley, T. (2008). Meta-regression methods for detecting and estimating empirical effects in the presence of publication selection. Oxford Bulletin of Economics and Statistics, 70(2), 103127.

Stanley, T., \& Doucouliagos, H. (2012). Meta-Regression Analysis in Economics and Business. New York: Routledge.

Stanley, T. D., \& Doucouliagos, H. (2010). Picture This: A Simple Graph That Reveals Much Ado about Research. Journal of Economic Surveys, 24(1), 170-191.

Stanley, T. D., \& Doucouliagos, H. (2014). Meta-regression approximations to reduce publication selection bias. Research Synthesis Methods, 5(1), 60-78.

Stanley, T. D., Doucouliagos, H., Giles, M., Heckemeyer, J. H., Johnston, R. J., Laroche, P., . . Rost, K. (2013). Meta-Analysis of Economics Research Reporting Guidelines. Journal of Economic Surveys, 27(2), 390-394.

Strauss, J., \& Thomas, D. (1998). Health, Nutrition and Economic Development. Journal of Economic Literature, 36, 766-817.

Stroup, M., \& Heckelman, J. (2001). Size Of The Military Sector And Economic Growth: A Panel Data Analysis Of Africa And Latin America. Journal of Applied Economics, 4(2), 329-360.

Sylwester, K. (2000). Income inequality, education expenditures, and growth. Journal of Development Economics, 63(2), 379-398.

Uzawa, H. (1965). Optimal technical change in an aggregate model of economic growth. International Economic Review, 6, 18-31.

Wigger, B. U. (2004). Are higher education subsidies second best? . Scandinavian Journal of Economics, 106, 65-82.

Yan, C., \& Gong, L. (2009). Government expenditure, taxation and long-run growth. Frontiers of Economics in China, 4(4), 505-525.

Zhang, J. (1996). Optimal public investment in education and endogenous growth. Scandinavian Journal of Economics, 98, 387- 404.

Zhang, J., \& Casagrande, R. (1998). Fertility, growth, and flat-rate taxation for education subsidies. Economics Letters, 60(2), 209-216. 
Table 1 - Overview of Evidence Base per Study (Simple \& Fixed Effect Weighted Means)

\begin{tabular}{|c|c|c|c|c|c|}
\hline Paper & $\begin{array}{c}\text { No. of } \\
\text { Estimates }\end{array}$ & $\begin{array}{l}\text { Simple } \\
\text { Mean }\end{array}$ & $\begin{array}{l}\text { Weighted Mean } \\
\text { (FE) }\end{array}$ & Significance & $\begin{array}{l}\text { Confidence } \\
\text { Interval }\end{array}$ \\
\hline \multicolumn{6}{|l|}{ Education } \\
\hline Afonso and Jalles (2013) & 21 & 0.1277 & 0.1335 & Yes & $(0.1072,0.1598)$ \\
\hline Barro and Sala-i-Martin (1995) & 24 & 0.1965 & 0.1988 & Yes & $(0.1557,0.2419)$ \\
\hline Barro and Sala-i-Martin (2004) & 1 & -0.1268 & -0.1268 & & \\
\hline Barro (1989) & 1 & 0.4035 & 0.4035 & & \\
\hline Blankenau et al. (2007) & 3 & -0.0495 & -0.0496 & No & $(-0.1600,0.0609)$ \\
\hline Bojanic (2013) & 3 & 0.1066 & 0.1091 & No & $(-0.2534,0.4716)$ \\
\hline Bose, Haque, and Osborn (2007) & 8 & 0.4340 & 0.4384 & Yes & $(0.3817,0.4950)$ \\
\hline Yan and Gong (2009) & 4 & -0.0175 & -0.0543 & No & $(-0.2292,0.1207)$ \\
\hline Colombier (2009) & 4 & -0.0161 & -0.0168 & No & $(-0.0537,0.0200)$ \\
\hline Cooray (2009) & 5 & 0.1331 & 0.1337 & Yes & $(0.0686,0.1989)$ \\
\hline Dalic (2013) & 12 & 0.0211 & 0.0237 & No & $(-0.0164,0.0641)$ \\
\hline Diamond (1998) & 1 & -0.0540 & -0.0540 & & \\
\hline Dunne and Mohammed (1995) & 3 & -0.0301 & -0.0301 & No & $(-0.2762,0.2160)$ \\
\hline Easterly and Rebelo (1993) & 3 & 0.0414 & 0.0414 & Yes & $(0.0186,0.0642)$ \\
\hline Hansson and Henrekson (1994) & 4 & 0.1407 & 0.1411 & Yes & $(0.0749,0.2073)$ \\
\hline \multirow{2}{*}{$\begin{array}{l}\text { Keller (2006) } \\
\text { Kelly (1997) }\end{array}$} & 18 & -0.0723 & -0.0070 & No & $(-0.3002,0.2862)$ \\
\hline & 12 & -0.1820 & -0.1852 & Yes & $\begin{array}{c}(-0.2414,- \\
0.1291)\end{array}$ \\
\hline Landau (1983) & 14 & 0.5665 & 0.5740 & Yes & $(0.5286,0.6195)$ \\
\hline Landau (1986) & 12 & 0.0267 & 0.0333 & Yes & $(0.0230,0.0435)$ \\
\hline Landau (1997) & 9 & -0.0396 & -0.0458 & No & $(-0.0939,0.0023)$ \\
\hline Miller and Russek (1997) & 6 & -0.0400 & -0.0871 & No & $(-0.2548,0.0806)$ \\
\hline Miyakoshi et al. (2010) & 9 & -0.0545 & -0.0372 & No & $(-0.0840,0.0095)$ \\
\hline Mo (2007) & 10 & -0.1268 & -0.1277 & Yes & $\begin{array}{c}(-0.1754,- \\
0.0800)\end{array}$ \\
\hline Neycheva (2010) & 27 & 0.3493 & 0.3248 & Yes & $(0.3008,0.3489)$ \\
\hline Perotti (1996) & 2 & 0.0796 & 0.0796 & No & $(-0.1293,0.2885)$ \\
\hline Singh and Weber (1997) & 3 & 0.7837 & 0.7839 & Yes & $(0.7639,0.8038)$ \\
\hline Stroup and Heckelman (2001) & 5 & 0.2027 & 0.2266 & Yes & $(0.0183,0.4348)$ \\
\hline Sylwester (2000) & 11 & 0.1264 & 0.1456 & No & $(-0.0417,0.3329)$ \\
\hline \multirow[t]{2}{*}{ Zhang and Casagrande (1998) } & 2 & 0.2586 & 0.2586 & Yes & $(0.1793,0.3380)$ \\
\hline & 237 & 0.1263 & 0.0828 & & \\
\hline \multicolumn{6}{|l|}{ Health } \\
\hline \multirow{3}{*}{$\begin{array}{l}\text { Afonso and Jal } \\
\text { Cooray (2009) } \\
\text { Dalic (2013) }\end{array}$} & 6 & -0.0046 & -0.0419 & No & $(-0.1285,0.0447)$ \\
\hline & 4 & 0.2258 & 0.2265 & Yes & $(0.1487,0.3043)$ \\
\hline & 12 & -0.0796 & -0.0794 & Yes & $\begin{array}{c}(-0.1405,- \\
0.0184)\end{array}$ \\
\hline Dao (2012) & 2 & -0.2212 & -0.2216 & Yes & $\begin{array}{c}(-0.3782,- \\
0.0651)\end{array}$ \\
\hline \multirow{2}{*}{$\begin{array}{l}\text { Easterly and Rebelo (1993) } \\
\text { Kelly (1997) }\end{array}$} & 3 & -0.0078 & -0.0078 & No & $(-0.0255,0.0100)$ \\
\hline & 12 & -0.1461 & -0.1483 & Yes & $\begin{array}{c}(-0.1876,- \\
0.1090)\end{array}$ \\
\hline \multirow{2}{*}{$\begin{array}{l}\text { Kneller et al. (1999) } \\
\text { Landau (1997) }\end{array}$} & 6 & 0.0034 & 0.0037 & No & $(-0.1010,0.1085)$ \\
\hline & 4 & -0.1100 & -0.1120 & Yes & $\begin{array}{c}(-0.2088,- \\
0.0153)\end{array}$ \\
\hline Miller and Russek (1997) & 6 & -0.1617 & -0.1775 & Yes & $\begin{array}{c}(-0.2456,- \\
0.1093)\end{array}$ \\
\hline Miyakoshi et al. (2010) & 9 & -0.0386 & -0.0292 & No & $(-0.0622,0.0039)$ \\
\hline Perotti (1996) & 2 & 0.4359 & 0.4383 & No & $(-0.1525,1.0291)$ \\
\hline \multirow[t]{2}{*}{ Singh and Weber (1997) } & 3 & -0.6451 & -0.7282 & Yes & $\begin{array}{c}(-1.1856,- \\
0.2709)\end{array}$ \\
\hline & 69 & -0.0739 & -0.0180 & & \\
\hline Combined Health \& Education & 306 & 0.0811 & 0.0535 & & \\
\hline
\end{tabular}


Table 2 - PET/FAT Results

\begin{tabular}{lccc}
\hline & $(1)$ & $(2)$ & $(3)$ \\
VARIABLES & Education & Health & E-H \\
\hline \multirow{3}{*}{ Precision $\left(\beta_{0}\right)$} & $0.0768 * * *$ & -0.0407 & $0.0790 * * *$ \\
& $(0.0267)$ & $(0.0473)$ & $(0.0255)$ \\
Bias $\left(\alpha_{0}\right)$ & 0.1000 & 0.1454 & -0.2148 \\
& $(0.4971)$ & $(0.9874)$ & $(0.4551)$
\end{tabular}

$\begin{array}{llll}\text { Observations } & 237 & 69 & 306\end{array}$

Standard errors in parentheses $* * * \mathrm{p}<0.01, * * \mathrm{p}<0.05, * \mathrm{p}<0.1$ 
Table 3 - MRA Results

\begin{tabular}{|c|c|c|c|c|c|c|}
\hline \multirow[b]{3}{*}{ VARIABLES } & \multicolumn{2}{|c|}{ PANEL A } & \multicolumn{2}{|c|}{ PANEL B } & \multicolumn{2}{|c|}{ PANEL C } \\
\hline & (1) & (2) & (3) & (4) & (5) & (6) \\
\hline & General & Specific & General & Specific & General & Specific \\
\hline Precision & $\begin{array}{c}0.2068 \\
(0.1339)\end{array}$ & $\begin{array}{c}0.2367 * * \\
(0.1166)\end{array}$ & $\begin{array}{c}0.0483 \\
(0.1358)\end{array}$ & $\begin{array}{c}0.0364 \\
(0.0865)\end{array}$ & $\begin{array}{c}0.1696 \\
(0.1810)\end{array}$ & $\begin{array}{c}0.1369 \\
(0.1267)\end{array}$ \\
\hline Health & & & & & $\begin{array}{l}-0.0258 \\
(0.0238)\end{array}$ & \\
\hline LDCs & $\begin{array}{c}0.0250 \\
(0.0433)\end{array}$ & & $\begin{array}{c}0.0443 \\
(0.0282)\end{array}$ & & $\begin{array}{c}0.0547 \\
(0.0342)\end{array}$ & \\
\hline OECD & $\begin{array}{l}-0.1441 \\
(0.1261)\end{array}$ & & $\begin{array}{c}-0.1556^{* * *} \\
(0.0654)\end{array}$ & $\begin{array}{c}-0.1462 * * \\
(0.0658)\end{array}$ & $\begin{array}{c}0.0626 \\
(0.0625)\end{array}$ & \\
\hline Control for Endogeneity & $\begin{array}{c}0.0265 \\
(0.0649)\end{array}$ & & & & $\begin{array}{c}0.0888 \\
(0.0651)\end{array}$ & \\
\hline Cross Section & $\begin{array}{c}0.3893 * * * \\
(0.0952)\end{array}$ & $\begin{array}{c}0.4320 * * * \\
(0.0758)\end{array}$ & & & $\begin{array}{c}0.0460 \\
(0.0342)\end{array}$ & $\begin{array}{c}0.0698 * * * \\
(0.0245)\end{array}$ \\
\hline Data Average*Panel Data & $\begin{array}{l}-0.0489 \\
(0.0904)\end{array}$ & & & & $\begin{array}{c}0.1425 \\
(0.0954)\end{array}$ & $\begin{array}{c}0.1597 * * \\
(0.0701)\end{array}$ \\
\hline Endogenous Growth Model & $\begin{array}{c}-0.1359 * * \\
(0.0612)\end{array}$ & $\begin{array}{c}-0.1150 * * \\
(0.0513)\end{array}$ & $\begin{array}{c}-0.3754 * * * \\
(0.0906)\end{array}$ & $\begin{array}{c}-0.3985 * * * \\
(0.0632)\end{array}$ & $\begin{array}{c}0.0082 \\
(0.0531)\end{array}$ & \\
\hline Data Average $(=>5)$ & $\begin{array}{c}0.3207 * * * \\
(0.1130)\end{array}$ & $\begin{array}{c}0.2502 * * * \\
(0.0774)\end{array}$ & $\begin{array}{l}-0.1151^{*} \\
(0.0612)\end{array}$ & $\begin{array}{c}-0.1331 * * * \\
(0.0506)\end{array}$ & $\begin{array}{c}0.0336 \\
(0.1244)\end{array}$ & \\
\hline Data Period (1980+) & $\begin{array}{c}0.0370 \\
(0.0688)\end{array}$ & & & & $\begin{array}{c}-0.1998 * * * \\
(0.0733)\end{array}$ & $\begin{array}{c}-0.2388 * * * \\
(0.0569)\end{array}$ \\
\hline Data Period (1990+) & $\begin{array}{c}-0.2871 * * * \\
(0.0872)\end{array}$ & $\begin{array}{c}-0.2842 * * * \\
(0.0766)\end{array}$ & & & $\begin{array}{c}0.4838 * * * \\
(0.1249)\end{array}$ & $\begin{array}{c}0.4513 * * * \\
(0.1170)\end{array}$ \\
\hline Data Period $(2000+)$ & $\begin{array}{c}0.0784 \\
(0.0588)\end{array}$ & & $\begin{array}{c}0.0998 * * * \\
(0.0302)\end{array}$ & $\begin{array}{c}0.1075 * * * \\
(0.0296)\end{array}$ & $\begin{array}{c}0.0107 \\
(0.0516)\end{array}$ & \\
\hline Population & $\begin{array}{c}-0.3079 * * * \\
(0.0695)\end{array}$ & $\begin{array}{c}-0.2989 * * * \\
(0.0573)\end{array}$ & $\begin{array}{c}-0.7575 * * * \\
(0.0673)\end{array}$ & $\begin{array}{c}-0.7804 * * * \\
(0.0509)\end{array}$ & $\begin{array}{c}-0.2752 * * * \\
(0.0823)\end{array}$ & $\begin{array}{c}-0.2671 * * * \\
(0.0746)\end{array}$ \\
\hline Initial GDP & $\begin{array}{c}0.1024 \\
(0.0883)\end{array}$ & & & & $\begin{array}{c}0.3414 * * * \\
(0.0709)\end{array}$ & $\begin{array}{c}0.2903 * * * \\
(0.0566)\end{array}$ \\
\hline Tax & $\begin{array}{l}-0.1037 * \\
(0.0548)\end{array}$ & $\begin{array}{c}-0.1315 * * * \\
(0.0492)\end{array}$ & $\begin{array}{l}-0.0112 \\
(0.0330)\end{array}$ & & $\begin{array}{c}0.0009 \\
(0.0453)\end{array}$ & \\
\hline Private Investment & $\begin{array}{l}-0.0148 \\
(0.0792)\end{array}$ & & $\begin{array}{c}-0.4846 * * * \\
(0.0887)\end{array}$ & $\begin{array}{c}-0.4807 * * * \\
(0.0682)\end{array}$ & $\begin{array}{c}-0.2111 * * * \\
(0.0595)\end{array}$ & $\begin{array}{c}-0.1957 * * * * \\
(0.0350)\end{array}$ \\
\hline Political Instability & $\begin{array}{c}-0.2360 * * * \\
(0.0864)\end{array}$ & $\begin{array}{c}-0.1885^{* * *} * \\
(0.0712)\end{array}$ & $\begin{array}{c}-0.1100 * * * \\
(0.0373)\end{array}$ & $\begin{array}{c}-0.1038 * * * \\
(0.0325)\end{array}$ & $\begin{array}{c}-0.3828 * * * \\
(0.0632)\end{array}$ & $\begin{array}{c}-0.3722 * * * \\
(0.0554)\end{array}$ \\
\hline Life Expectancy & $\begin{array}{c}0.4781 * * * \\
(0.1259)\end{array}$ & $\begin{array}{c}0.4051 * * * \\
(0.0937)\end{array}$ & $\begin{array}{c}-0.2966^{* * *} * \\
(0.0696)\end{array}$ & $\begin{array}{c}-0.3292 * * * \\
(0.0594)\end{array}$ & $\begin{array}{c}0.0002 \\
(0.1046)\end{array}$ & \\
\hline Government Quality & $\begin{array}{c}-0.3520 * * * \\
(0.1076)\end{array}$ & $\begin{array}{c}-0.2930 * * * \\
(0.0843)\end{array}$ & $\begin{array}{l}-0.1623^{*} \\
(0.0872)\end{array}$ & $\begin{array}{c}-0.1549 * * \\
(0.0655)\end{array}$ & $\begin{array}{l}-0.0659 \\
(0.0467)\end{array}$ & $\begin{array}{c}-0.0950 * * * \\
(0.0361)\end{array}$ \\
\hline Journal Rank & $\begin{array}{l}-0.1440^{*} \\
(0.0783)\end{array}$ & $\begin{array}{l}-0.1158^{*} \\
(0.0692)\end{array}$ & $\begin{array}{c}0.0185 \\
(0.0549)\end{array}$ & & $\begin{array}{c}-0.2662 * * * \\
(0.0989)\end{array}$ & $\begin{array}{c}-0.2476 * * * \\
(0.0724)\end{array}$ \\
\hline Journal & $\begin{array}{c}0.2162 * * \\
(0.0919)\end{array}$ & $\begin{array}{c}0.2150^{* *} \\
(0.0845)\end{array}$ & $\begin{array}{c}0.3736 \text { *** } \\
(0.0441)\end{array}$ & $\begin{array}{c}0.4065 * * * \\
(0.0344)\end{array}$ & $\begin{array}{l}-0.1150 \\
(0.1210)\end{array}$ & \\
\hline Publication Year (1990+) & $\begin{array}{c}-0.3989 * * * \\
(0.1077)\end{array}$ & $\begin{array}{c}-0.3383 * * * \\
(0.0942)\end{array}$ & $\begin{array}{c}-0.2472 * * * \\
(0.0504)\end{array}$ & $\begin{array}{c}-0.2675 * * * \\
(0.0383)\end{array}$ & $\begin{array}{c}0.1416 \\
(0.1302)\end{array}$ & $\begin{array}{l}0.1953 * \\
(0.1120)\end{array}$ \\
\hline Publication Year (2000+) & $\begin{array}{c}0.0923 \\
(0.0710)\end{array}$ & $\begin{array}{c}0.1273 * * \\
(0.0583)\end{array}$ & & & $\begin{array}{c}0.0733 \\
(0.0802)\end{array}$ & \\
\hline Constant & $\begin{array}{c}0.1448 \\
(0.5124)\end{array}$ & $\begin{array}{c}0.0493 \\
(0.5063)\end{array}$ & $\begin{array}{c}0.0266 \\
(0.6279)\end{array}$ & $\begin{array}{c}0.0588 \\
(0.5527)\end{array}$ & $\begin{array}{l}-0.8291 \\
(0.6309)\end{array}$ & $\begin{array}{c}-0.7694 \\
(0.5678)\end{array}$ \\
\hline Observations & 237 & 237 & 69 & 69 & 306 & 306 \\
\hline Number of groups & 29 & 29 & 12 & 12 & 31 & 31 \\
\hline
\end{tabular}


Figures 1 - 3

Education (1)

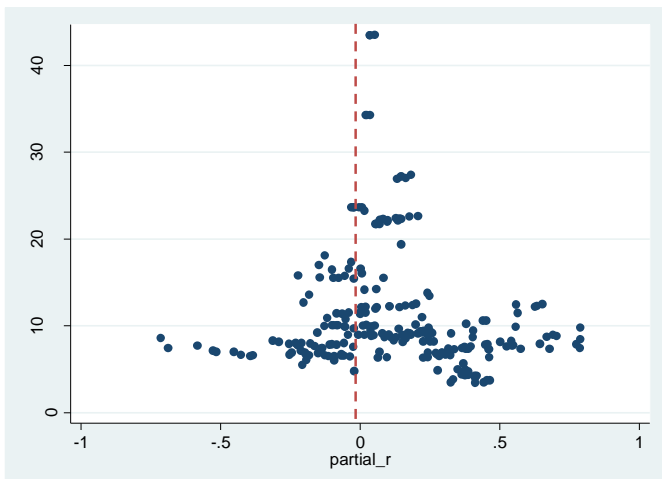

Health (2)

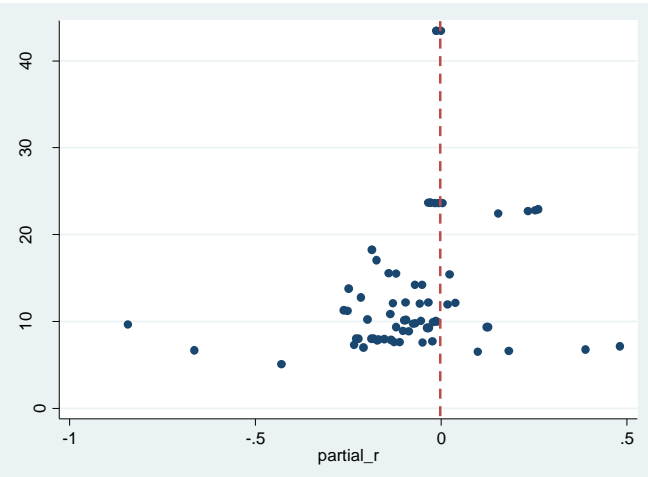

The Combined Human Capital (3)

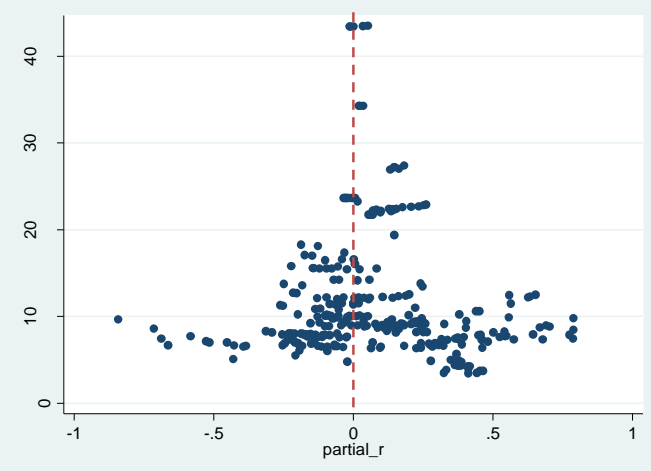


Appendix Table A1 (MRA Variables)

\begin{tabular}{|c|c|c|c|c|c|}
\hline \multirow[b]{2}{*}{ Variables } & \multirow[b]{2}{*}{ Definition } & \multicolumn{2}{|c|}{ Education } & \multicolumn{2}{|c|}{ Health } \\
\hline & & Mean & S.D. & Mean & S.D. \\
\hline$t$-value & t-statistics reported in primary studies & 1.17 & 2.39 & -0.62 & 2.12 \\
\hline Precision & $\begin{array}{l}\text { Inverse of standard error of the partial correlation } \\
\text { coefficient }\end{array}$ & 4.28 & 2.01 & 3.41 & 2.36 \\
\hline$S E_{r i}$ & $\begin{array}{l}\text { Standard errors of the partial correlation } \\
\text { coefficients }\end{array}$ & 0.11 & 0.05 & 0.09 & 0.03 \\
\hline OECD & $\begin{array}{l}\text { Takes value } 1 \text { if the primary study data is from } \\
\text { OECD countries, otherwise } 0\end{array}$ & 0.19 & 1.48 & 1.07 & 2.96 \\
\hline LDCs & $\begin{array}{l}\text { Takes value } 1 \text { if the primary study data is from } \\
\text { LDCs, otherwise } 0\end{array}$ & 2.21 & 5.86 & 0.86 & 4.01 \\
\hline Cross-section & $\begin{array}{l}\text { Takes value } 1 \text { if cross-section data is used by } \\
\text { primary study, } 0 \text { if panel is used }\end{array}$ & 3.54 & 6.74 & 0.41 & 1.65 \\
\hline Panel Data & $\begin{array}{l}\text { Takes value } 1 \text { if panel data is used by primary } \\
\text { study, otherwise } 0\end{array}$ & 7.54 & 7.74 & 12.69 & 9.14 \\
\hline Control for Endogeneity & $\begin{array}{l}\text { Takes value } 1 \text { if primary study controls for } \\
\text { endogeneity, otherwise } 0\end{array}$ & 1.72 & 3.84 & - & - \\
\hline $\begin{array}{l}\text { Endogenous Growth } \\
\text { Model }\end{array}$ & $\begin{array}{l}\text { Takes value } 1 \text { if the model is based on endogenous } \\
\text { growth model, otherwise } 0 \text {. }\end{array}$ & 5.11 & 8.67 & 7.09 & 10.61 \\
\hline Data Average $(=>5)$ & $\begin{array}{l}\text { Takes value } 1 \text { if data averaging period is }=>5 \\
\text { otherwise } 0\end{array}$ & 6.26 & 6.10 & 2.07 & 3.96 \\
\hline $\begin{array}{l}\text { Data Average*Panel } \\
\text { Data }\end{array}$ & $\begin{array}{l}\text { Takes value } 1 \text { if study used panel data and } \\
\text { averaging period is }=>5 \text { otherwise } 0\end{array}$ & 3.75 & 6.25 & 1.66 & 3.78 \\
\hline $\begin{array}{l}\text { Data Average*Cross } \\
\text { Section }\end{array}$ & $\begin{array}{l}\text { Takes value } 1 \text { if study used cross section and } \\
\text { averaging period is }=>5 \text { otherwise } 0\end{array}$ & 2.52 & 4.14 & 0.40 & 1.65 \\
\hline Data Period $(1970+)$ & Takes value 1 if data year $>=1970$, otherwise 0 & 7.93 & 8.18 & 6.62 & 8.29 \\
\hline Data Period (1980+) & Takes value 1 if data year $>=1980$, otherwise 0 & 2.66 & 5.79 & 0.67 & 3.18 \\
\hline Data Period $(1990+)$ & Takes value 1 if data year $>=1990$, otherwise 0 & 2.40 & 5.54 & 9.93 & 9.90 \\
\hline Data Period $(2000+)$ & Takes value 1 if data year $>=2000$, otherwise 0 & 2.40 & 5.54 & 5.53 & 8.51 \\
\hline Initial GDP & $\begin{array}{l}\text { Takes value } 1 \text { if the primary study control for } \\
\text { initial per capita GDP, otherwise } 0\end{array}$ & 5.73 & 7.98 & 6.23 & 10.10 \\
\hline Population & $\begin{array}{l}\text { Takes value } 1 \text { if the primary study control for } \\
\text { population, otherwise } 0\end{array}$ & 2.55 & 4.32 & 1.98 & 4.57 \\
\hline Private Investment & $\begin{array}{l}\text { Takes value } 1 \text { if the primary study control for } \\
\text { private investment, otherwise } 0\end{array}$ & 4.31 & 7.78 & 1.67 & 3.22 \\
\hline Tax & $\begin{array}{l}\text { Takes value } 1 \text { if the primary study control for } \\
\text { taxes, otherwise } 0\end{array}$ & 5.51 & 9.41 & 8.66 & 10.68 \\
\hline Journal Rank & $\begin{array}{l}\text { Takes value } 1 \text { if the primary study is published in } \\
\text { high-ranked journal, otherwise } 0\end{array}$ & 6.07 & 8.79 & 6.31 & 9.46 \\
\hline Journal & $\begin{array}{l}\text { Takes value } 1 \text { if the primary study is published in a } \\
\text { journal, otherwise } 0\end{array}$ & 9.72 & 8.15 & 11.45 & 9.84 \\
\hline $\begin{array}{l}\text { Publication Year } \\
(1990+)\end{array}$ & $\begin{array}{l}\text { Takes value } 1 \text { if publication year }>=1990 \text {, otherwise } \\
0\end{array}$ & 9.68 & 7.24 & 7.06 & 8.54 \\
\hline $\begin{array}{l}\text { Publication Year } \\
(2000+)\end{array}$ & $\begin{array}{l}\text { Takes value } 1 \text { if publication year }>=2000, \text { otherwise } \\
0\end{array}$ & 6.39 & 7.27 & 9.37 & 8.56 \\
\hline $\begin{array}{l}\text { Publication Year } \\
(2010+)\end{array}$ & $\begin{array}{l}\text { Takes value } 1 \text { if publication year }>=2010 \text {, otherwise } \\
0\end{array}$ & 3.69 & 7.01 & 5.75 & 7.73 \\
\hline
\end{tabular}

